TITLE: BEAM-BREAKIJP CALCULATIONS FOR THE DARHT ACCELERATOR

aUthor(s): P. Allison, M-4, Los Alames Natinnal Laboratory M. J. Burns, M-4, Los Alamos National Laboratory G. J. Caporaso and A. G. Cole, Lawrence Livermore National Laboratcry

submitted to: 1991 IEEE Partfcle Accelerator Conference May 6-9, 1991 Sherator, Palace Hotel, San Francisco, CA

\title{
DISCLAIMER
}

This repart was prepared as an acxownt of work sponwred by an agency of the ! Inited Sitales Government. Neither the Unilod Siates tiovernment mer any ajency thoreof, nor any of their employoes, mates any warianty, oxprese of implied, of asurmes any legal liability of responatbillity for the securacy, completeneas, of usefulness of any information, apparatun, product, or procens disclused, of reprosents that itt une would net infringe privalely owned rights. Reference herein lo any speciffec commercial product, procers, ar wervise hy trade name, Irademart. manufacturer, or othorwive dese nul necousarily conntitute or imply its endorwoment, recommendation, or favoring by the Iniled Stalos (iovernment of any ajency therear. The vrows

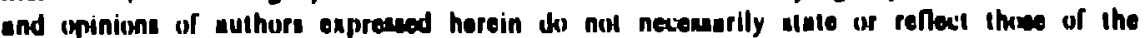
Innitod Siales fiovernmont or any agency thereof. 


\section{Beam-Breakup Calculations for the DARHT Accelerator*}

\section{Paul Allison, Micnael J. Bums, Los Alamos National Laboratory, and Geurge J. Caporaso, Art. G. Cole, Lawrence Livermore National Laboratory}

\begin{abstract}
We have modeled an induction linac that will accelerate a 4-MeV, 3-kA beam of electrons to 16- to $20-\mathrm{MeV}$ in 64 gaps. To suppress beam-breakup (BBU) instabilitics induced by excitation of $\mathrm{rf}$ deflecting modes, the growth factor $\Gamma$ must be kept sufficientiy small (e.g. <3). On prototype DARHT cavities, If measurements have shown that the normally degenerate TM modes are split in frequency by the asymmetry that the two pulsed.power drive rods present to the cavily. If half the cavities had vertical and half had horizontal drive-rod orientations, the effective number of gaps would be reduced by half if there were no coupling between the modes by the solenoidal focusing and if the split modes had no overlap. The LLNL code BREAKUP was used to study BBU growth for drive rod alternation patterns of blocks of $1,2,4$, $8,16,24,32$, or 64 (no altemation) for both constant and alternating polarity solenoids. For altemating polarities the optimum aliernation pattem is $\mathbf{2}$ or $\mathbf{4}$, whereas for constint polarities BBU is approximately independent of patter.
\end{abstract}

\section{INTRODUCTION}

The theory of BBU for induction [1] linacs has been developed for some time. For an accelerating beam, the theory (2) shows that if the beam tas stcady-state radial oscillations of amplitude $\delta r_{0}$ at the linac entrance, then after $n$ successive cavities the umplitude growth $g=\delta \mathrm{r} / \delta \mathrm{r}_{0}=\mathrm{c} \Gamma$, with

$$
\left.\Gamma_{\mathrm{a}}=[\mathrm{ni}(\omega) / \mathrm{c}) / \mathrm{c} \mathrm{B}_{0}\right]\left[2 /\left(\mathrm{V}\left(\mathrm{r} / \gamma_{0}\right)+1\right)\right]
$$

where $(\omega Z / c) / Q=c\left(\int B_{y} d z\right)^{2} / 2 U$ is the uansver:e cuvity impedance, $U$ is the stored energy in the cavity, $n$ is the number of accelerating cavities, $i$ is the current, and $B_{0}$ is the rins solenoidal ficld. The nowtion $\Gamma_{a}$ is used lo distinguish this unalytic upproximution from the value calculuted by the code. To reduce the centroid motion ("corkscrew") resulting frem misnlignments and energy spread, the toul phase advance $\phi=\int(\mathrm{Bd} z / 2 \mathrm{~B} \rho)$ should be minimized [2]. For a given $\Gamma$ this is achieved if the solenoidal fields increase with beam energy us $B_{0}\left(\gamma / \gamma_{0}\right)^{1 / 2}$. As a design criterion for DARHT (sec imodel parameters in Tuble 1), we uke a gruwth factor ge20, or l'-3

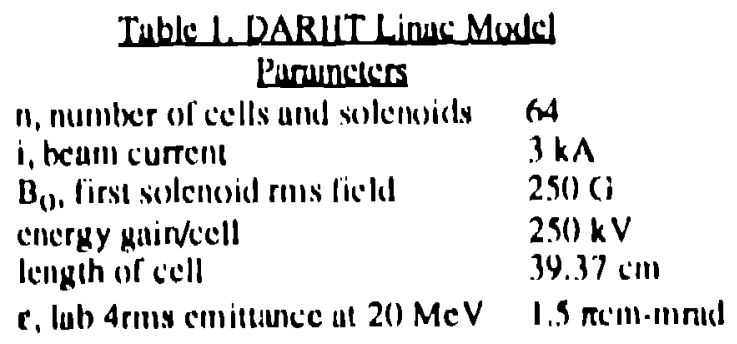

as an upper limit. The maximum value of $B_{10}$ is limited by

- Work performed under the auspices of the U. S. Depurtument at lincing beam stability considerations, a general criterion for which is that the phase advance per cell not be too large. We will use the notation $\times \mathbf{B}=1,1.5,2$ to denote ficld profiles that are 1 , 1.5, and 2 times larger than $250 \mathrm{C} \mathrm{ms}$ in the first cell. For $x_{B}=2$, in the first magnet $\phi_{O}=0.7 \mathrm{rad}$, a reasonable upper limit for centroid motion stability and minimum corkscrew.

Since the ferrites exposed to the interior of the accelerating cavity are very lossy $(\mu-3-20 \mathrm{i}$ at $400 \mathrm{MHz})$ [3], the cavilies have low Q's. The Briggs model [4] of a pillbox cavity with a resistive outer wall is uscful in understanding the approximate parametric dependence of the cavity impedance. The impedunce at the nominally $\mathrm{TM}_{110}$ mode resonance is $\omega Z / c=\left(g / \pi b^{2}\right) Z_{0} \eta$, where $Z_{0}-377 \Omega, b$ is the inner bearn pipe radius, $g$ is the accelerating gap, and $\eta$ is a function of wall impedance $Z_{S}$ and the outer cavily radius. We anticipate that $\eta=0.7-2$, so $\omega Z / C=(80-240) \mathrm{g} / \mathrm{b}^{2}$.

For accelerating stress $E_{0}, \mathrm{nE}_{\mathrm{og}}$ is the total linic voluge guin $V$. Then I' $a \mathrm{~V} /\left(E_{0} b^{2} \mathrm{~B}\right)$, independent of the number of cells $n$. To minimize $\Gamma$, we choose the maximum $E_{0}$ consistent with sparking criteria. Cost and ferrite availability have led to the choice b-7.5 cm, and so $\omega Z / c-22()$ $\Omega / \mathrm{m}$ at $Q-1$ for gap $\mathrm{g}=1.5 \mathrm{~cm}$ from the Briggs model at $x_{13}=2$, with $Q \leq 3$ required for $370 \Omega / m$ to make $\Gamma_{\llcorner}<3$.

The Briggs model provides guidance; the AMOS colle (5) models cavities more gencrally using a wave impeuilnce boundary condition at the ferite surface. Recent cavily impedance measurements $|6|$ with ferrites in posilion ked lo code inodifications to treat the ferrites as having un effectivi volume magnetic-conductivity, $\sigma_{m}=\omega \mu "$ ", with $\mu$ " being the imaginary part of the permeability.

Each cell is is connecled to two power cubles with drive royls $180^{\circ}$ apan. An importunt result of the measuremicms was that the rods split the normully degenerate TM I I0 IIIskl's in frequency by $\mathbf{2 0 \%}$, and the impedance curves for the (w') planes did not overlap substuntiully (Fig. 1). Mode splitting

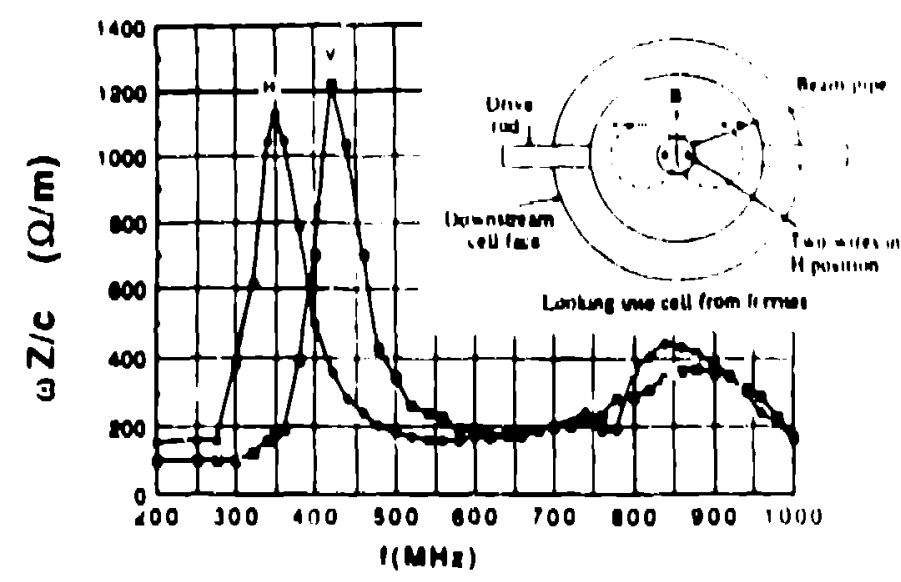

fig. I Vertical and lurizantal impedmeses of test cavily 
led to the idea of a stagger tuning, for which tne azimuthal orientation of the drivc rods would be alternated in some pattem between horizontal $(H)$ and vertical $(V)$ alignment, reducing $\Gamma$ by half in the absence ot mode overlap. For constant solenoid polarity, beam rotation by the solenoids might be expected $w$ average the impedances and make grow. results insensitive to cell orientation patterns. Since earh solenoid rotates the beam by $-40^{\circ}$, coupling $x$ - and $y$ - motion, it is tiot clear that simple alternation of the orientation would be the best strategy. The use of altemating polarities may be advantagcous in minimizing corkscrew motion at high $B_{0}$.

\section{CALCULATIONS}

The 9REAKUP [7] code was modified so that each cell could have independent modes for horizontal or for verical motion. The notation $\Gamma_{+}$and $\Gamma_{ \pm}$will be used to denote the growth factors calculated for constant and for alternating polarity solenoids, respectively. The mode paramelers given in Table 2 are based on measurements [6] on the first cell design.

\section{Table 2 Cavily Pirameters}

$\begin{array}{lclcc}\text { Mode } & f(\mathrm{MHz}) & \mathrm{Q} & \omega \mathrm{Z} / \mathrm{c}(\Omega / \mathrm{m}) & {[\omega \mathrm{\omega} / \mathrm{c}] \max (\Omega / \mathrm{m})} \\ \text { la } & 357 & 5 & 673 & -417 \\ \text { Ib } & 430 & 6 & 1173 & -677 \\ \text { 2a } & 890 & 3 & 354 & - \\ \text { 2b } & 860 & 3.75 & 253 & -\end{array}$

With stagger tuning, $\Gamma$ should be approximately proportional (1) the average vertical and horizontal impedance $\omega Z / S=$ $\omega\left(Z_{H}+Z_{V}\right) / 2 c$ (Fig. 2). The maximum occurs near 430 MH $z$,

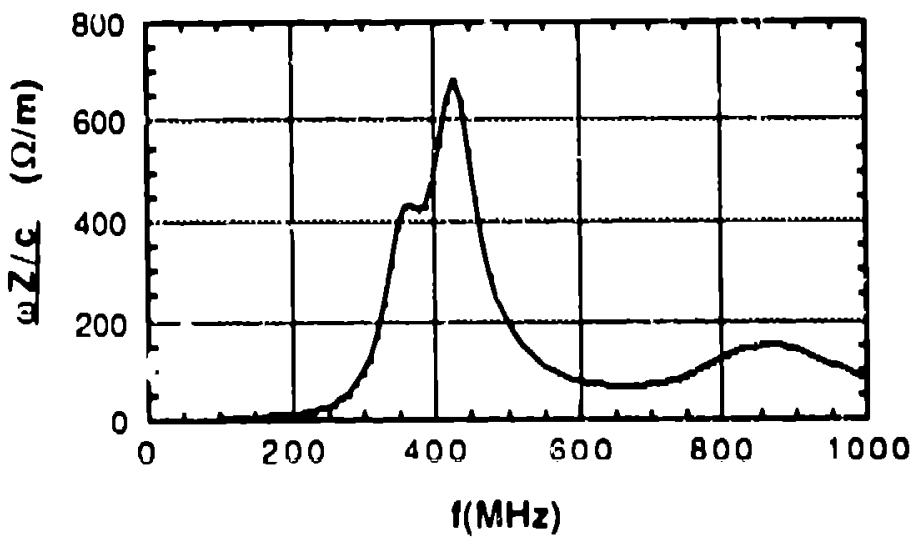

likg. 2 Average of vertical und horizontal infped ance for modes of liable?

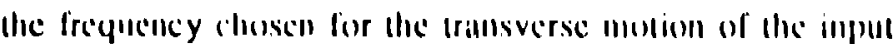

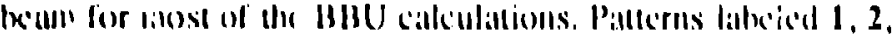
.. ot have sell urive-rod orichlallioll allerllating every cell, inblocks of (wo, ...or hlocks of (ot (II) nlleribution), with the lirst cedl ul mays having H oricmlallion.

The heidn al injection was pive" Iralleverse

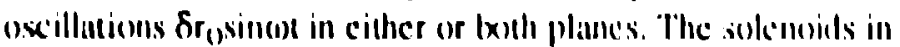
lle linac could be given random tilss $\delta($ ) ( lo values) wilh

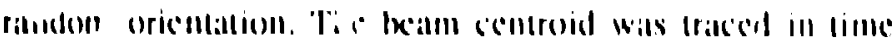

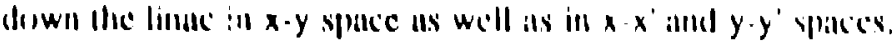

Since the beam envelope radius $R$, calculated with the envelope code ETRACEM [8], decreases by approximately a factor of 2.5 down the linac, $g$ would be about 0.4 in the absence of growth.

The $x-x^{\prime}$ or $y-y^{\prime}$ phase space that is traced out by the beam at the cxit can be used to calculate an emitlance growth factor $\delta \varepsilon / \varepsilon$ for determining permissible BBU growth. The cenuroid motion at the linac exit is found to be approximately given by $x=\delta x$ ssin $\omega t$ and $x^{\circ}=\delta x p \cos \omega t$, and the beam phaseellipse boundary is given approximately by $x=R \sin \alpha$ and $x^{\prime}=k R \cos \alpha$, with $0 \leq \alpha \leq 2 \pi$. Then $\varepsilon=k R^{2}$, with $k=B / 2 B p=$ $0.0045 \times \mathrm{B} / \mathrm{cm}$. For a uniform disuribution within the boundary, the smearing of the final emiltance by centroid motion leads to a time-averaged $\mathrm{rms}$ growth factor $\delta \varepsilon / \varepsilon=2\left(\delta x_{f} / R\right)^{2}$. For $\delta \varepsilon / \varepsilon<10 \%$, then $\delta x_{[}=g x_{0}<0.22 R$. For $x_{B}=2, R=7 \mathrm{~mm}$, requiring $\mathrm{gx} \mathrm{x}_{\mathrm{O}}<1600 \mu \mathrm{m}$, or $\mathrm{g}<20$ for $\mathrm{x}_{\mathrm{O}}=80 \mu \mathrm{m}$.

When the mode asymmetry was eliminated by giving mode $1 \mathrm{~b}$ the parameters of mode $1 \mathrm{a}$, then $\omega Z / \mathrm{c}=1173 \Omega / \mathrm{m}$ at $430 \mathrm{MHz}$. We calculated $\Gamma_{ \pm}=12.9$ and $\Gamma_{+}=11.2$ tor $\times \mathrm{B}=1$, about $0.6 \Gamma_{\mathrm{a}}$. Using the modes of Table 2 again, growth was calculated for orientation patterns $1,2,4,8,24,32,64$. Pattern 24 was chosen because the phase advance in the lirst 24 cells is approxmately the same as in the last 40 . The input beam was given a transverse amplitude of $25 \mu \mathrm{m}$ al $430 \mathrm{Mli} \%$ in the $H$ plane. As expected, $\Gamma_{+}$was fairly insensitive to the pallem (Fig. 3), ranging from 7.5 to 5.5 , but $\Gamma_{ \pm}$ranged from

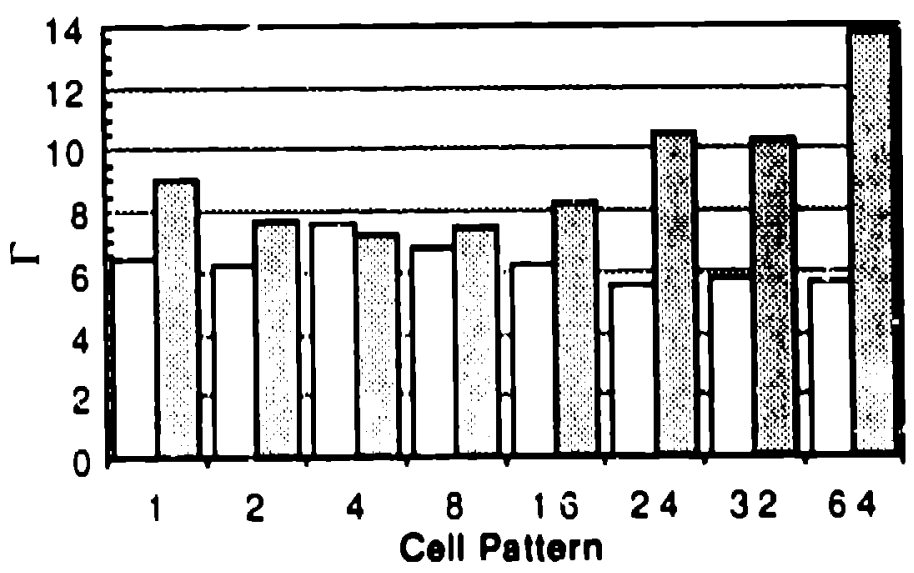

Fig. $3 \Gamma(I X)$ ys moxle patcem for conswnt - (open) and for altemating-|x)larily (shaded) solencids

13.8 (6) 7. Pattern \& give the smallest $\Gamma_{t}$ hut the highest l, patlern 2 was chosen for most of the rest of llae studis hecause it had low growth for both case's alld becaluse wl mechanical assembly considerations. The comstant polatrlly solenoid tune had the lowest growth. Pattern of gave very

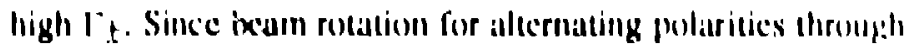

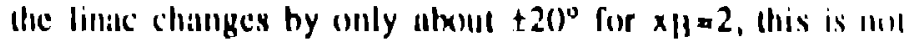

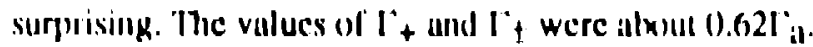

('hanging the plane of the transverse uscillation ficum II I1) $V$ reduced $r_{ \pm}(F i g .4)$ by $2.25 \%$. Since $\times 13 \Gamma$ should be

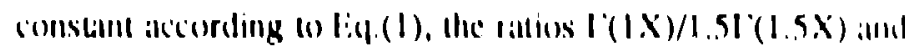

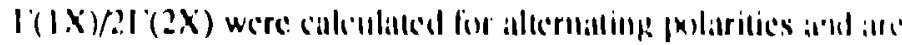
scron lo be close to unity with a fow exceptions (fig. 5). Then 
was no evident dependence of $\Gamma$, within $\pm 1 \%$, on $\delta \theta$ in the range 0 - to 5 -mrad in any of the calculations. We anticipate that DARHT misalignments will not exceed these values and

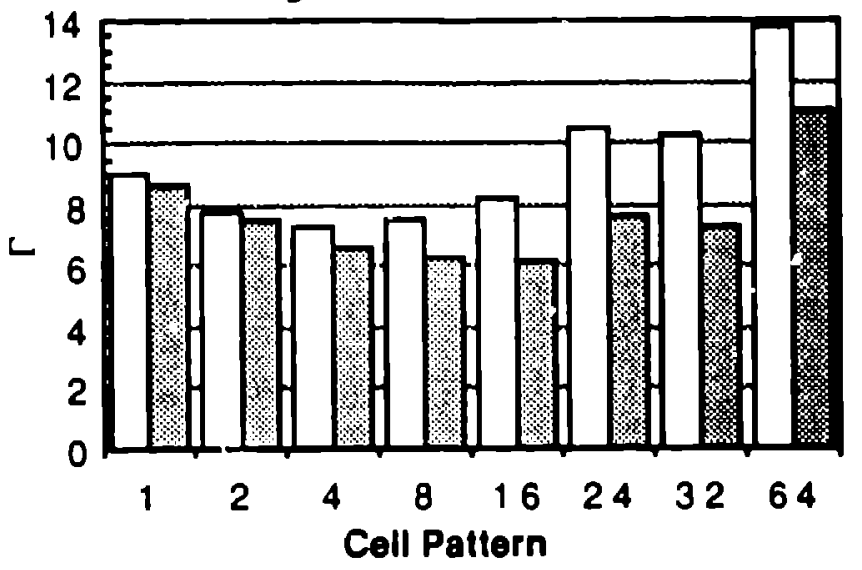

Fig.4 $\Gamma_{ \pm}(\mathrm{IX})$ vs mode pauem for intial beam oscillation in $H$ - (open) and V. (shaded) planes

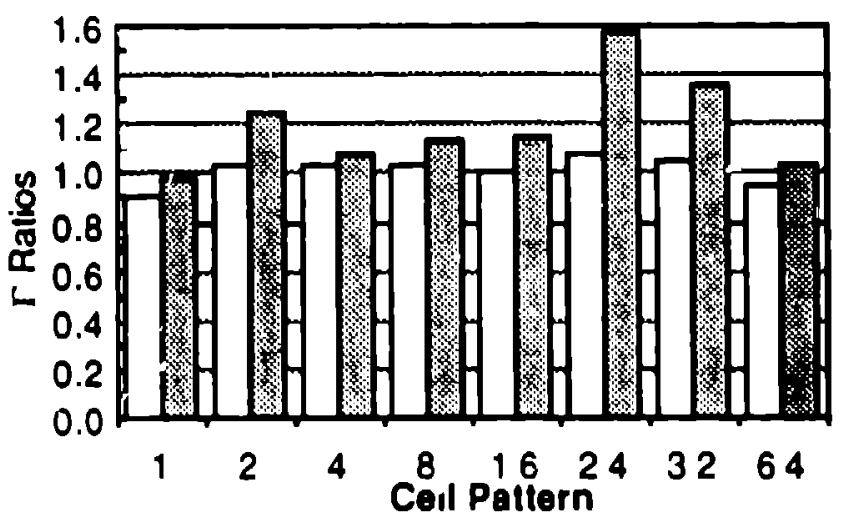

Fig. 5 Rauios $\Gamma(1 X) / 1.5 \Gamma(1.5 X)$ (open) and $\Gamma((1 X) / 2 \Gamma(2 X)$ (shaded) vs mode pattem for altemating polaritics

that with stesring corrections applied, the effective $\delta \theta$ will be much less. To test the parametris Jependence of $\Gamma$ on $\omega Z / c$, we sel the inpul oscillation frequency at $357 \mathrm{MHz}$, for which frequency $\omega Z / c=417 \Omega 2 / \mathrm{m}, 62 \%$ of the 430 )-MHz value. The results (Tuble 3) follow the predicted scaling with $B$ better at $430 \mathrm{MHz}$ than al $357 \mathrm{MHz}$.

Table $3 \Gamma$ for the two dominant frequencies vs $\times B$

$\begin{array}{lllllc}\times B & \Gamma_{430} & x_{H} \Gamma_{430} & \Gamma_{357} & \times_{B} \Gamma_{357} & \left(\Gamma_{357 / \Gamma_{43}}\right) \\ 1 & 7.7 & 7.7 & 7.8 & 7.8 & 1.01 \\ 1.5 & 5 & 7.5 & 4 & 6 & 0.8 \\ 2 & 3.1 & 6.2 & 2.2 & 4.4 & .71\end{array}$

The beam from the REX injeciur [9] has transverse motion of $I(X) \mu \mathrm{m}$ at $235 \mathrm{MIlz}$ and of $25 \mu \mathrm{m}$ at 47() $\mathrm{MH} / \mathrm{s}$ at approximately the linac injection point. BREAKUP calculations showed that for $\times B-1$, damper oscillations with amplitudes - I cill are excited at cither $1.57 \mathrm{MHz}$ or $4.30 \mathrm{M} / \mathrm{lz}$. making it difficule to estimute the stealy-stale gain. For $x=2$, the transicut damps quickly. The gatins are $-(0,5$ and 1,7 , or $\Gamma_{t}=-0.7$ and 0.4 , as compared wilh $\Gamma_{i}-(0.15$ and 3 . respectively. Thus there is essentially no gain at $235 \mathrm{MHz}$, considering the beam compression factor.

If the beam has no initial transverse oscillation, magnet and beam alignment errors will cause transient excitation of BBU oscillations at $430 \mathrm{MHz}$. The maximum peak-peak amplitude at the linac exil during the "flat top" part of the beam pislse for random angular errcrs $\delta \theta$ from 1 - to 5 mrad in the absence of initial beam motion. A good approximation to the results was $\delta r_{m a x}(\mathrm{~cm})=$ $(0.072 \pm 0.015) 6 \theta / x_{B}$. with the uncertainty being due to the scalter inherent in statistical misalignment crrors. Applying the emitunce growth criterion, $\delta \theta<4 \mathrm{mrad}$ is required for $x_{B}=2$. This cmittance critcrion is probably too strict, as the tansient damps with a time constant $\tau(n s)=24 / x_{B}$.

\section{CONCLUSIONS}

The cell-orientation pattern 2 appears to be the best choice for DARHT from BBU growth and mechanical Jesign considerations for alternating polarities. The code-calculated values of $\Gamma$ are approximately $60 \%$ of the analyticallycalculated value $\Gamma_{\ldots}$, and the parameiric dependence is approximatcly the same. Solenoid misalignment do not contribute significantly to growth. For the DARHT design parameters and the expected cell impedances, growth is less than 20 at the $430-\mathrm{MHz}$ resonance, and considerably lower at those frequencies for which the REX injecto beam has measurable transverse oscillation. Growih is lower for constiunt- than for altemating-polarity solenoids.

\section{References}

[1] V. K. Neil, L. S. Hall, R. K. Cooper, "Furiher Theoretical Studics of the Beam Breakup Instability", Particle Acceler ators, Vol.9. (1979) pp.213.222

12) George J. Caporeso and Richard J. Briggs. "High Current Electron-Bewn Transport in Induction Linucs". Proc. Beijirg FEL Semine, Wold Scientific 1989

[3] J. F. DeFord and C. Kamin. "Application of Lincar Magnetic Luss Model of Ferrile is 'nduction Cavity Simulation". Proc 1990 Linear Aciclerator inf., Albuquerque, NM. Seps. IW)

(A) K. J. Briges, D. L. Birx, G. J. Caporaso, V. K, Nul, and T. C. Genoni, "Theoretical and Experimental Investigution of the Interaction Inpedances and $Q$ Values of the Acceleritling Cells in the Advanced Test Accelerator". Particle Accolerulors, 18, (1985) 41

(5) J. F. DeFord, G. J. Craig, and R. K. MicLeod, "The AM()S Wakeficld Code". Proc. Conf. Compuler Codes and the Lintiar Accelcrating Conmunity, p.265, Li)s Alumos, NM, Jun $2:$ 25. $19 \%()$

|6| L. Wulling, P'uul Allison. M. Burm, D. J. Liskil, and A. II Shapiro, "Transverse lmpedance Measurements of Prolotype"

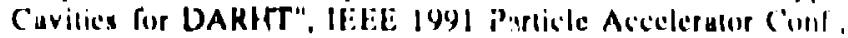
Sun Fruncisco. May 1991

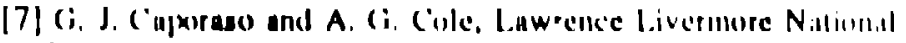
Lulxeralory

[K] K. K. C'rundall, D. P. Kusthui, "T'RAC'L: An Inleraciive

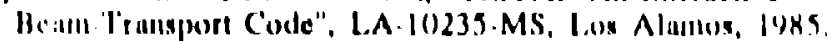

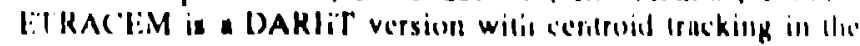
presence of misnlignument errors.

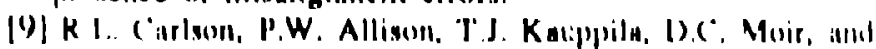

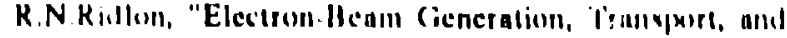

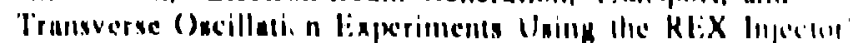

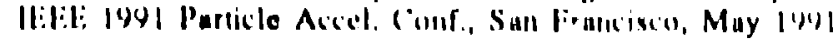

